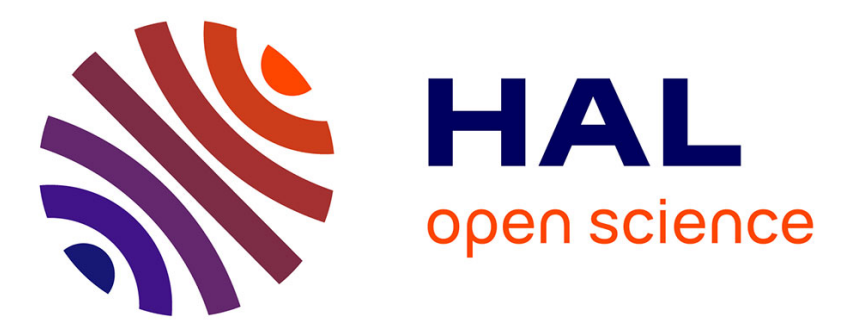

\title{
Semantic interoperability for an integrated product development process: a systematic literature review
}

Anderson Luis Szejka, Osiris Canciglieri Júnior, Hervé Panetto, Eduardo Rocha Loures, Alexis Aubry

\section{- To cite this version:}

Anderson Luis Szejka, Osiris Canciglieri Júnior, Hervé Panetto, Eduardo Rocha Loures, Alexis Aubry. Semantic interoperability for an integrated product development process: a systematic literature review. International Journal of Production Research, 2017, 55 (22), pp.6691-6709 10.1080/00207543.2017.1346314 . hal-01537847

\section{HAL Id: hal-01537847 \\ https://hal.science/hal-01537847}

Submitted on 15 Jun 2017

HAL is a multi-disciplinary open access archive for the deposit and dissemination of scientific research documents, whether they are published or not. The documents may come from teaching and research institutions in France or abroad, or from public or private research centers.
L'archive ouverte pluridisciplinaire HAL, est destinée au dépôt et à la diffusion de documents scientifiques de niveau recherche, publiés ou non, émanant des établissements d'enseignement et de recherche français ou étrangers, des laboratoires publics ou privés. 


\title{
Semantic interoperability for an integrated product development process: a systematic literature review
}

\author{
Anderson Luis Szejka ${ }^{1}$, Osiris Canciglieri Júnior ${ }^{1}$, Hervé Panetto ${ }^{2,3}$, \\ Eduardo Rocha Loures ${ }^{1}$, and Alexis Aubry ${ }^{2,3}$ \\ ${ }^{1}$ Industrial and Systems Engineering Graduate Program (PPGEPS), Polytechnic School \\ at Pontifical Catholic University of Paraná-PUCPR - Rua Imaculada Conceição, \\ 1155, Curitiba, Paraná, Brazil.
}

${ }^{2}$ Research Centre for Automatic Control of Nancy (CRAN), University of Lorraine (UL), BP 70239, 54506 Vaudoeuvre-lès-Nancy, France.

\section{${ }^{3}$ CNRS / CRAN UMR 7039, France}

Anderson Luis Szejka is the corresponding author. He is Lecturer in the Polytechnic School and Researcher in the Industrial and Systems Engineering Graduate Program (PPGEPS) at Pontifical Catholic University of Paraná - PUCPR - Brazil - Phone: +55 4184157430 or +55 413271 2425 - e-mail: anderson.szejka@pucpr.br

Osiris Canciglieri Junior is a full professor and Director of Industrial and Systems Engineering Graduate Program (PPGEPS), in the Polytechnic School at Pontifical Catholic University of Paraná - PUCPR - Brazil. Phone: +55 4132711304 -e-mail: osiris.canciglieri@pucpr.br

Hervé Panetto is a full professor at the CRAN, UL - France. Phone: +33 (0) 383684426 - email: herve.panetto@univ-lorraine.fr

Eduardo Rocha Loures is a full professor of Industrial and Systems Engineering Graduate Program - PPGEPS, in the Polytechnic School at Pontifical Catholic University of Paraná PUCPR - Brazil - Phone: +55 4132712579 - e-mail: eduardo.loures@pucpr.br

Alexis Aubry is an associate professor at the CRAN, UL - France. Phone: +33 (0) 383684302 e-mail: alexis.aubry@univ-lorraine.fr

Acknowledgments: The authors would like to thank the Coordination for the Improvement of Higher Education Personnel - CAPES, under Science without Borders Program (Special Visiting Researcher) - Project 178/2012 and Pontifical Catholic University of Parana (PUCPR) for financial support. 


\section{Semantic interoperability for an integrated product development process: a systematic literature review}

Global competitiveness challenges manufacturing industry to rationalise different ways of bringing to the market new products in a short lead-time with competitive prices while ensuring higher quality levels and customisation. Industries need to effectively share heterogeneous information during Product Development Process (PDP) within and across their institutional boundaries to be competitive. However, problems with misinterpretation and mistakes have been identified during information exchange due to the semantic interoperability obstacles. Thus, this research proposes a systematic literature review to identify the main researches and the milestones reference works on semantic interoperability field. A rigorous methodology was conducted in different databases, covering the articles published in scientific journals from 2005 to 2015 as a preliminary study had indicated that the incidence of articles related to the subject was more frequent from the second half of the 2000s. The research structure consisted of four steps: Survey - searching, analysis and selection of recent researches; Categorization - categorization of the selected papers; References citation frequency analysis - the selected papers were analysed and the main researches and milestones references were identified; and Main researches critical analysis - the main researches were analysed for their contributions and limitations, their contributions and limitations, resulting in 14 selected scientific articles and 8 identified milestones references. It is evident that this field has interesting perspectives on future research opportunities on semantic interoperability of information issues across PDP, contributing to the new concepts of future factories.

Keywords: Product Development Process, Product Requirements, Multiple Domains, Bibliography Survey, Product Design and Manufacturing, Interoperability.

\section{Introduction}

Nowadays, Product Development (PD) is ruled by the need to speed up the new product launch and market expansion while ensuring higher quality, customization levels and lower production costs (Chungoora et al., 2013; Panetto, Dassisti and Tursi, 2012; 
Canciglieri and Young, 2010). This challenge is aligned with the new concept of smart factories that are seeking flexibility and intelligence in their manufacturing systems and are automatically supporting the decision-making (Schlechtendahl et al., 2015). One concept of the future factories to remain competitive is the collaboration environment in which all stakeholders can share information across the product design and manufacturing domains (Imran and Young, 2016). PD has undergone continuous improvements in its processes to achieve such capabilities mainly by using the power of Information and Communications Technologies (ICT) to reduce the data loss across different phases of Product Development Process (PDP).

Companies use different scientific and technological sources across PDP, embodying different characteristics and perspectives to meet the customers' needs (Quintana-García and Benavides-Velasco, 2008). PD begins with the requirements' definitions based on customers' needs. These requirements are declarations from the needs of stakeholders and/or customers to identify a product, system or process characteristics or constraints (BKCASE, 2016, ISO/IEC 42010, 2007)

Requirements define the constraints and characteristics of a product and their information must be effectively shared across different phases of PDP without any loss of the meaning. However, PDP is a set of structured and transdisciplinary activities for developing a product design and manufacturing based on the market's needs, business possibilities and technological constraints (Pereira and Canciglieri Junior, 2016; Rozenfeld et al., 2006). Thus, specialists from multiple fields (mechanical engineering, electrical engineering, computational engineering, marketing and business) and different partners work together in different phases of PD creating and sharing information and resources to solve engineering problem (Penciuc et al., 2014). 
Semantic problems can be identified across PDP, although a requirement must be clear, unambiguous, unique, consistent, stand-alone, measurable, testable and verifiable (BKCASE, 2016). Different PDP players do not use the same taxonomy (Zeng and Chan, 2009, Wang and Zhang, 2008) and each one builds its own view with specific information about the Product Design and Manufacturing (Penciuc et al., 2014). Thus, requirements' misinterpretation and mistakes have been identified during the product design and manufacturing phases owing to the heterogeneity information (Canciglieri and Young, 2003; Canciglieri and Young, 2010; Chungoora et al., 2013; Szejka, et al., 2014; Liao et al., 2015; Imran and Young, 2016; Palmer et al., 2017).

There are different interoperability concepts (technical interoperability, semantic interoperability, and organizational interoperability). This research focused on the semantic interoperability concept, as it is the only that ensures the effective information sharing in a collaborative and heterogeneous environment. Moreover, the information relationships obstacles across PDP are typical semantic interoperability issues. Thus, different semantic interoperability approaches have emerged and corroborated to create a formalisation of information and knowledge to support different phases of PDP. Based on that, the aim of the present research is to identify the milestone works and the references to support the semantic interoperability across PDP, contributing to providing a better understanding and subsidising new approaches in this knowledge field.

\section{Problem Statement in Integrated Product Development Process}

Modern Product Development Process (PDP) has been requiring simultaneous multiple groups collaborations, producing and exchanging knowledge and information from multi-perspectives such as Product Domain, Product Development Cycle, Product Constraints, Product Data (functional, behaviour, etc.), Product Decomposition and so 
on, within and across institutional boundaries. This process is complex and not trivial since all information from those multi-perspectives must be simultaneously shared in an effective and efficient manner. However, misinterpretation and mistakes have been evidenced across the product design and manufacturing due to unclear, implicit and ambiguous information, which can be considered as semantic obstacles.

These semantic obstacles directly affect the product design and manufacturing and are typical problem of semantic interoperability (Negri et al., 2016; Gunendran and Young, 2007). Semantic interoperability is achievable when the captured information and knowledge can be effectively exchanged in a collaborative environment without any information and knowledge meaning and intent loss during this process (Chungoora, Canciglieri Junior and Young, 2010).

Although there are multi-perspectives to PDP, this research considers the semantic interoperability issues between the product domains and the different phases of PDP since they naturally overlap each other and are related to the same product. Here, as product domains were considered "Mouldability", "Geometric Dimension and Tolerance", "Function", "Material", "Machining Resource" and so on, which are associated to the same product, resulting in a multi-domains models (Canciglieri Junior and Young, 2010; Chuungoora et al., 2013; Imran and Young, 2016; Palmer et al., 2016). As PDP phases, it was considered Conceptualization, Design, Manufacturing, Utilization, Maintenance and Disposal. The Product Domains and PDP relations are the constraints that guide the evolution of the product development (Szejka et al., 2016). To illustrate all the concepts described previously, Figure 1 gives an example of the relations between multi-domains, PDP and their constraints during the development of a plastic injection moulded product, which are the multiple perspectives explored in this research. 
Figure 1 Dependence relations in the Product Development Process.

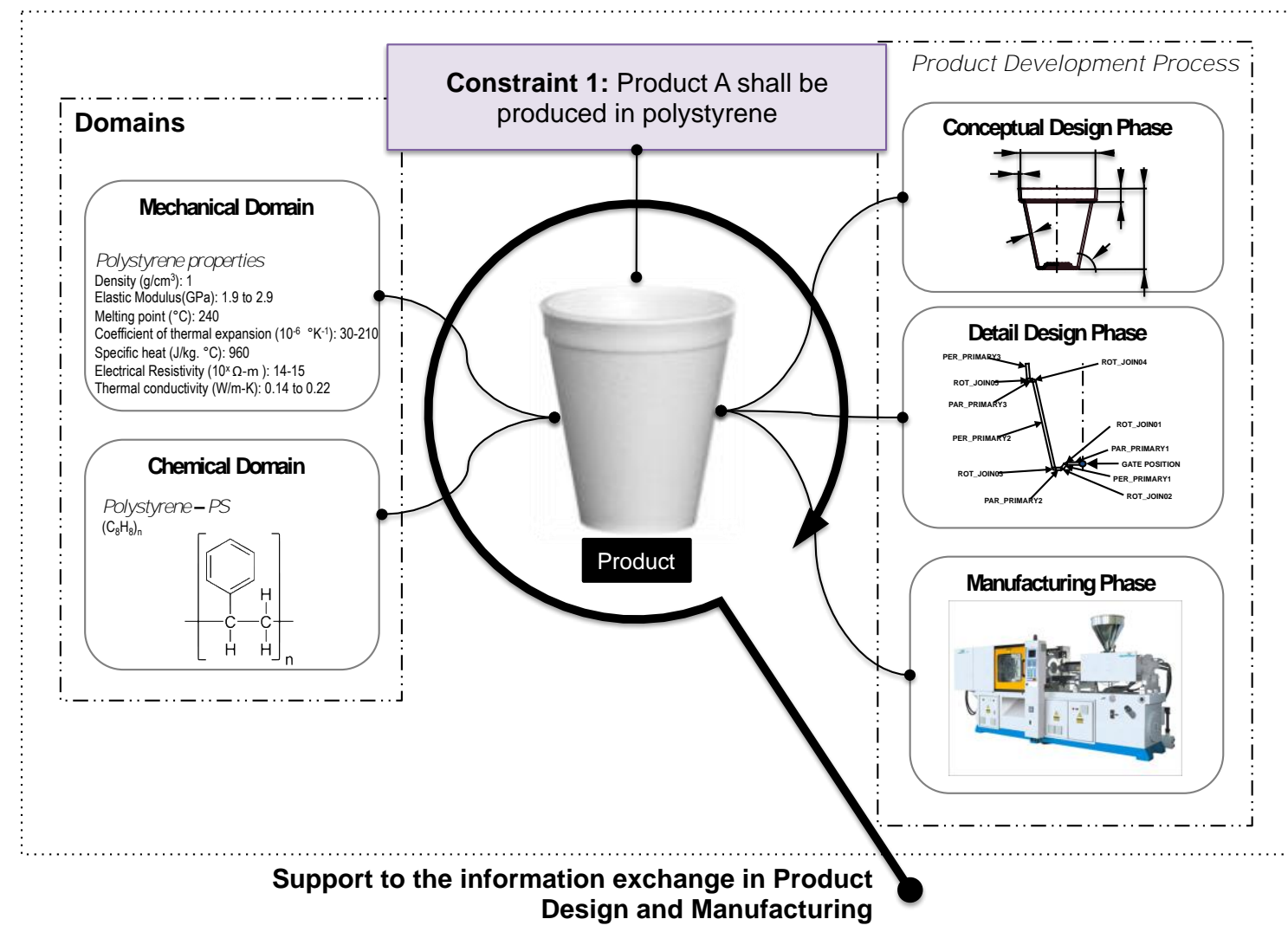

As shown in Figure 1, three perspectives must be simultaneously considered during the product design and manufacturing. These perspectives are as follows:

- Domains perspective - different fields are involved during the product development, for example, mechanical engineering, electrical engineering, computer science, etc. Each specialist produces and shares information with other domains in order to design or manufacture the product;

- PDP perspective - this perspective refers to information sharing across different phases of the product development cycle, where each phase has its proper constraints and specific information. In addition, each phase impacts directly in the future and previous ones. It impacts the future phase because the results of the actual phase are the input of the next one. It affects the previous phase because any change in the actual phase needs to be tracked in the previous one if there are changing impacts; 
- Product requirements or constraints perspective - it concerns the consistency and coherency of the relation between requirements and/or constraints, as well as their impacts in the associated domain and PDP phase.

Each perspective has different semantic issues to provide an interoperable product design and manufacturing process. However, the three perspectives must be simultaneously considered to find an effective solution to a given problem, which brings a new issue that is the relationship of the three other interoperability perspectives. So that, Figure 2 was proposed with three axes that represent the Domain perspective, the PDP perspective and the Product Requirement and Constraint perspective.

Figure 2 Semantic Interoperability of Information Issues.

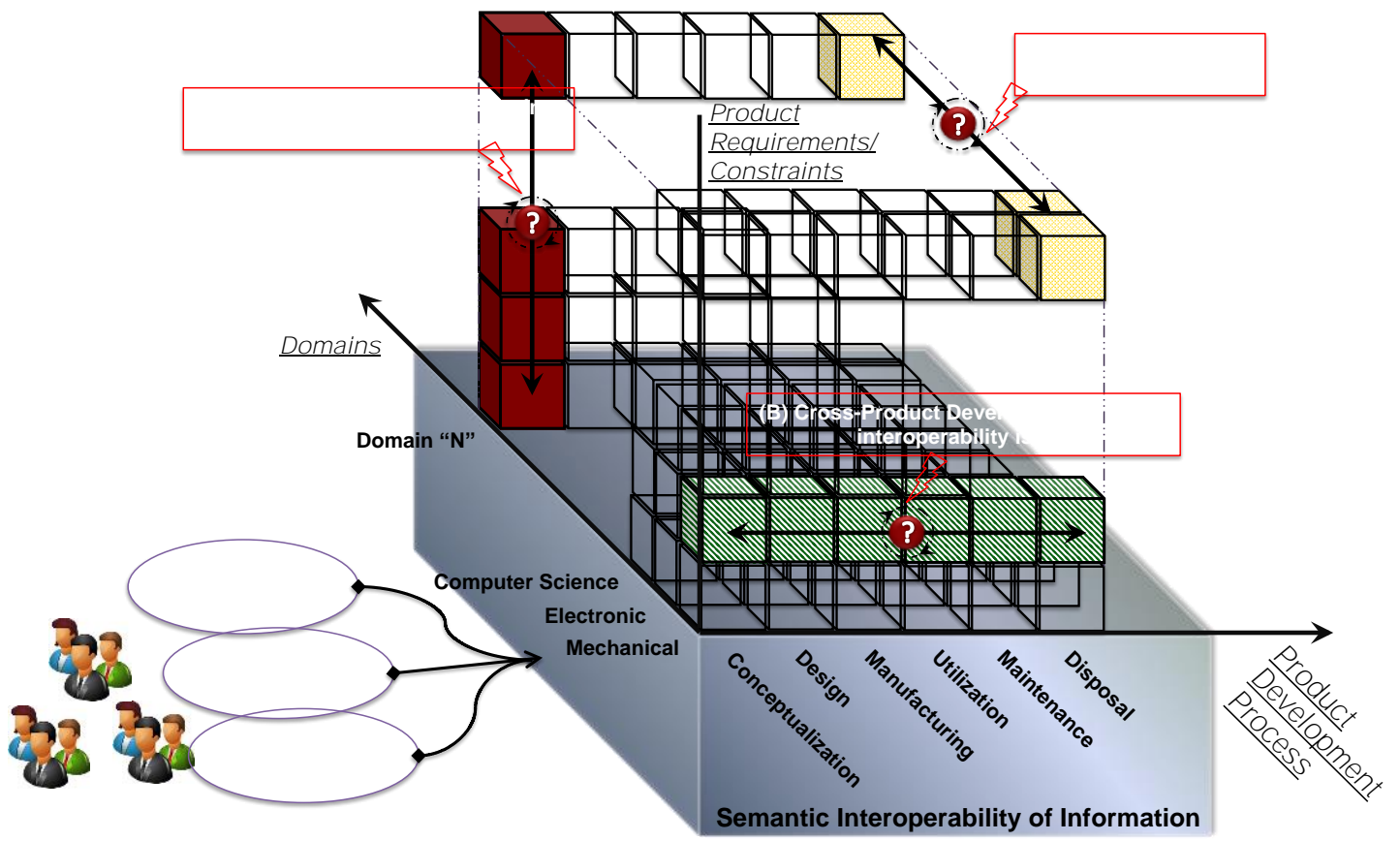

Source: Based on Szejka et al., 2014.

Three information interoperability issues are identifiable in ment and Constraint perspective.

Figure 2. The first interoperability issue concerns the heterogeneity of information coming from multiple domains (ment and Constraint perspective. 
Figure 2 - Detail “A”). It imposes some information and knowledge formalisation and their semantic relationships. The second interoperability issue concerns the product development process (ment and Constraint perspective.

Figure 2 - Detail "B"). Although information can be associated with multiple phases of PDP, it is developed in a specific phase and shared with others as well as its relationships must be well defined. Finally, the third interoperability issue concerns the relations between product requirements or constraints and their properties (completeness, coherency, uniqueness, univocity, verifiability and traceability associated with each of them - ment and Constraint perspective.

Figure 2 - Detail “C”).

In light of this problem statement, this research searches the identification of the main works relating to these three interoperability issues as well as their contributions and limitations in order to support the information semantic interoperability in the Product Design and Manufacturing.

\section{Research Methodology}

The problem statement depicted the main obstacles in the semantic interoperability in product design and manufacturing. A systematic literature review based on the three identified issues (Figure 2) was proposed to identify the main studies and milestones references in the subject of this research, deepening the knowledge and understanding on the research's issues and their solutions. Preliminarily, a literature survey regarding researches that directly investigate the three perspectives working simultaneously showed to be unfruitful. So that, the literature survey was initially focused on PDP and Multiple Domains and subsequently, it was focused on PDP and Product Requirements (Constraints). The relationship between Multiple Domains and Requirements was not explored since this relationship may not regard the PDP issues 
that are the research scope. Based on the results, a categorization for the found studies was proposed to identify the ones that were the most adherent to the aim of this research.

The first phase of the work consisted in the implementation of a rigorous and well-defined method to structure the systematic review. A systematic review is a research method that achieves the results from information already described in the published literature to minimise distortions and errors (Jesson and Lacey, 2006). Therefore, it is important to define the review structure to carry out the systematic review. This work took into account and adapted different methods from: "Preferred Reporting Items for Systematic Review" (Moher et al., 2009); "Determining the principal references of the social life cycle assessments of products" (Mattioda et al., 2015) and "Systematic literature review in social life cycle assessment" (Petti, Ugaya and Di Cesare, 2016).

This systematic review included the period of 2005-2015 based on the preliminary study results (Szejka et al., 2015 and Szejka et al., 2014), which indicated that the incidence of articles related to the research subject was more frequent from the second half of the 2000s. The systematic review was conducted according to the following steps:

- Step 1 - Survey: searching, analysis, and selection of recent researches;

- Step 2 - Categorization: categorization of the papers selected in the previous step;

- Step 3 - References citation frequency analysis: the selected papers were analysed in order to define the frequency of reference citation and to identify main researches and milestones references in the ICT community; 
- Step 4 - Main researches critical analysis: the main researches underwent a content analysis to identify their contributions and limitations.

\subsection{The research questions}

The Problem Statement (Section 2) has shown an interdependence among Multiple Domains of Knowledge (Detail "A" of Figure 2), Product Development Process (Detail "B" of Figure 2), Product Constraints (Detail "C" of Figure 2) and the simultaneous relationship among them in the interoperable product design and manufacturing. Therefore, the information and knowledge handling in an Interoperable Product Design and Manufacturing requires: (a) formal information and knowledge structures to ensure the correct meaning associated to the captured information; and (b) formal well-defined relationships to ensure the correct interchangeable information and knowledge across the product development.

According to the research statement, it was defined the main questions to handling the requirements of information and knowledge in an Interoperable Product Design and Manufacturing, that were:

- (i) What are the recent papers regarding the formalisation of heterogeneous information and product requirements (constraints) to provide a seamless semantic interoperability across PDP?

- (ii) What are the recent papers regarding the formalisation of information relationships from multiple domains to support a seamless semantic interoperability across PDP?

The research's questions were essentials for the survey keywords definition as well as for the evaluation of the papers. 


\subsection{Inclusion/Exclusion criteria and Source selection}

The parameters for identifying the main works relating to this study were essential to answer the research questions and to reduce the probability of bias. Thus, table 1 shows inclusion and exclusion criteria used to develop the systematic review.

Table 1. Inclusion/Exclusion criteria used during the systematic review development.

\begin{tabular}{|c|c|}
\hline Inclusion Criteria & Exclusion criteria \\
\hline $\begin{array}{l}\text { - } \text { Product Development Process keywords } \\
\text { - } \text { Multiple Domains keywords } \\
\text { - Product Requirements (Constraints) keywords } \\
\text { - Studies published between January } 2005 \text { and October } \\
2015 \\
\text { - } \quad \text { Primary studies }\end{array}$ & $\begin{array}{ll}\text { - } & \text { Secondary studies } \\
\text { - } & \text { Duplicate studies } \\
\text { - } & \text { Non-English written papers } \\
\text { - } & \text { Specific Domain papers } \\
& \text { Redundant paper of the same author }\end{array}$ \\
\hline
\end{tabular}

The main inclusion criteria are the keywords relating to the problem statement and to the two research questions: (i) Product Development Process (PDP); (ii) Multiple Domains; and (iii) Product Requirements (constraints). For each one was identified the main keywords used in the literature, as shown in " 1 "”, " $2^{+} "$ and " 3 "” of table 2. Furthermore, the included studies covered a time span range from 2005 to 2015.

The survey was carried out through the Brazilian scientific database system (Periodicos CAPES) provided by Coordination for the Improvement of Higher Education Personnel (CAPES, 2017) which contains 532 databases, including Cambridge Journals Online, Emerald Insight (Emerald), IEEE Xplore, Scopus (Elsevier), Science Direct, SpringerLink, Taylor \& Francis and so on. The Brazilian scientific database system enables papers searching and filtering in higher impact factor journals, primary studies, reviewed by pairs, and so on.

\subsection{Research Structure Method of the Systematic Review}

Based on every issue presented, table 2 summarizes the research structure with the 
objectives and methodological criteria for each of the research steps. Moreover, the keywords used in this research are presented in " 1 "”, " 2 "”, and " 3 "”.

Table 2. Research Structure.

\begin{tabular}{|c|c|c|c|c|}
\hline $\begin{array}{l}\text { Question of } \\
\text { research/Papers }\end{array}$ & Research Steps & Databases & Type Analysis & Research Keys \\
\hline $\begin{array}{l}\text { (i) What are the recent } \\
\text { papers regarding the } \\
\text { formalisation } \\
\text { heterogeneous } \\
\text { information and product } \\
\text { requirements } \\
\text { (constraints) in order to } \\
\text { provide a seamless } \\
\text { semantic interoperability } \\
\text { across PDP? }\end{array}$ & $\begin{array}{l}\text { Step 1a: Selection and } \\
\text { analysis of recent } \\
\text { researches related to PDP } \\
\text { and Multiple Domains. } \\
\text { Step 1b: Selection and } \\
\text { analysis of recent } \\
\text { researches related to PDP } \\
\text { and Product Requirements } \\
\text { (Constraints). }\end{array}$ & $\begin{array}{l}\text { Periodicos } \\
\text { CAPES } \\
\text { Cambridge } \\
\text { Journals Online, } \\
\text { Emerald Insight } \\
\text { (Emerald), IEEE } \\
\text { Xplore, Scopus } \\
\text { (Elsevier), } \\
\text { Science Direct, } \\
\text { SpringerLink, } \\
\text { Taylor \& Francis, } \\
\text { and so on. }\end{array}$ & $\begin{array}{l}\text { Documental } \\
\text { Survey of the } \\
\text { researches } \\
\text { published in } \\
\text { scientific } \\
\text { journals during } \\
\text { the period } 2005 \\
\text { to } 2015 \text {. }\end{array}$ & $\begin{array}{l}\text { Searching for } \\
\text { some specific } \\
\text { terms }\left(1^{*}\right),\left(2^{+}\right) \text {e } \\
\left(3^{\#}\right) \text { on titles, } \\
\text { abstracts, } \\
\text { keywords and } \\
\text { on the main } \\
\text { body of the } \\
\text { researches } \\
\text { published. }\end{array}$ \\
\hline $\begin{array}{l}\text { (ii) What are the recent } \\
\text { papers regarding the } \\
\text { formalisation } \\
\text { information } \\
\text { relationships from } \\
\text { multiple domains in order } \\
\text { to support a seamless } \\
\text { semantic interoperability } \\
\text { across PDP? }\end{array}$ & $\begin{array}{l}\text { Step 2: Categorization of } \\
\text { the relevant researches. } \\
\text { Step 3: Analysis of all the } \\
\text { references cited on the } \\
\text { recent researches related } \\
\text { to Multiple Domains and } \\
\text { Product Requirements } \\
\text { (Constraints) to support } \\
\text { PDP. } \\
\text { Step 4: Main researches } \\
\text { critical analysis. }\end{array}$ & $\begin{array}{l}\text { All scientific } \\
\text { researches } \\
\text { selected in steps } \\
\text { (1a) and (1b). }\end{array}$ & $\begin{array}{l}\begin{array}{l}\text { Analysis of } \\
\text { titles } \\
\text { abstracts. }\end{array} \\
\text { Analysis of all } \\
\text { researches } \\
\text { published. } \\
\text { Analysis of the } \\
\text { cited references } \\
\text { in the researches } \\
\text { published. }\end{array}$ & $\begin{array}{l}\begin{array}{l}\text { Selection } \\
\text { specific } \\
\text { studies. }\end{array} \\
\text { case } \\
\begin{array}{l}\text { Type } \\
\text { publication and } \\
\text { years. }\end{array}\end{array}$ \\
\hline
\end{tabular}

(1*) PDP - (i) Integrated Product Development; (ii) Product Development Process; (iii) Product Design; (iv) Manufacturing Design; and (v) Design for Manufacturing and Assembly.

$\left(2^{+}\right)$Multiple Domains - (i) Multiple Domains; (ii) Heterogeneous Domains; and (iii) Multiple Perspective.

$\left(3^{\#)}\right.$ Product Requirements (Constraints) - (i) Requirements; (ii) Specification.

\section{Results and Discussion}

This section presents the application of the research methodology's three steps in order to determine the main research works and milestones references for supporting the semantic interoperability in an integrated product development process. It was carried out the search regarding PDP and Multiples Domains as well as PDP and Product Requirements, but the search for Multiple Domains and Product Requirements was not realised because this particular relationship may not concern PDP issues, which is this study addressed approach. The section 4.1 presents the search results regarding PDP and Multiples Domains; section 4.2 presents the search results regarding PDP and 
Product Requirements (Constraints); and section 4.3 presents the categorization of the results from section 4.1 and 4.2 regarding the scientific papers that concern simultaneously PDP, Multiple Domains and Product Requirements (Constraints).

\subsection{Step 1a: Scientific papers related to PDP and Multiples Domains}

In light of the methodology presented in section 3, this step identified the scientific papers related to PDP and multiple domains. The research on databases was performed in the article title, abstract, and keywords according to the inclusion criteria, as presented in table 1. The following keywords were used to represent PDP - Integrated Product Development, Product Development Process, Product Design, Manufacturing Design, Design for Manufacturing and Assembly; and to represent Multiple Domains were used the keywords - Multiple Domains, Heterogeneous Domains, and Multiple Perspectives. The search covered a period of 10 years (2005-2015). This first search resulted in 777 articles as illustrate in table 3.

Table 3. Results obtained regarding PDP and Multiple Domains according to the selected keywords.

\begin{tabular}{llll}
\hline Keywords & & & $\begin{array}{l}\text { Results from } \\
\text { databases }\end{array}$ \\
\hline "Product Development Process" & AND & "Multiple Domains" & 42 \\
"Integrated Product Development" & AND & "Multiple Domains" & 20 \\
"Product Design & AND & "Multiple Domains" & 114 \\
"Manufacturing Design" & AND & "Multiple Domains" & 102 \\
"Design for Manufacturing and Assembly" & AND & "Multiple Domains" & 8 \\
"Product Development Process" & AND & "Heterogeneous Domains" & 13 \\
"Integrated Product Development" & AND & "Heterogeneous Domains" & 8 \\
"Product Design & AND & "Heterogeneous Domains" & 8 \\
"Manufacturing Design" & AND & "Heterogeneous Domains" & 31 \\
"Design for Manufacturing and Assembly" & AND & "Heterogeneous Domains" & 5 \\
"Product Development Process" & AND & "Multiple Perspective" & 114 \\
"Integrated Product Development" & AND & "Multiple Perspective" & 23 \\
"Product Design & AND & "Multiple Perspective" & 145 \\
"Manufacturing Design" & AND & "Multiple Perspective" & 138 \\
"Design for Manufacturing and Assembly" & AND & "Multiple Perspective" & 6 \\
\hline
\end{tabular}


The exclusion criteria proposed in table 1 was applied on the results of Table 3, resulting in 39 articles from the 777 articles. The main exclusion criterion was the domain-specific papers because many articles had a divergent research question focus such as medicine, business, marketing, etc. Thus, the abstract of every article was analysed according to the aim and questions of this research and focused on the fields of Product Design and Manufacturing.

Table 4 Results of the Systematic Literature Review on PDP and Multiple Domain, organised by authors.

\begin{tabular}{|c|c|c|}
\hline Authors & Year & Title \\
\hline Augustine et al. & 2012 & $\begin{array}{l}\text { Cognitive map-based system modeling for identifying interaction failure } \\
\text { modes }\end{array}$ \\
\hline Bartolomei et al. & 2012 & $\begin{array}{l}\text { Engineering Systems Multiple-Domain Matrix: An organizing framework } \\
\text { for modelling large-scale complex systems }\end{array}$ \\
\hline Brusoni and Prencipe & 2006 & Making Design Rules: A Multi-domain Perspective \\
\hline Canciglieri Jr. and Young & 2010 & $\begin{array}{l}\text { Information mapping across injection molding design and manufacture } \\
\text { domain }\end{array}$ \\
\hline Chen; Wang and Huang & 2014 & $\begin{array}{l}\text { A negotiation methodology for multidisciplinary collaborative product } \\
\text { design }\end{array}$ \\
\hline Christiansen et al. & 2010 & Living Twice: How a Product goes through Multiple Life Cycles \\
\hline $\begin{array}{l}\text { Chungoora; Canciglieri Jr. } \\
\text { and Young }\end{array}$ & 2010 & $\begin{array}{l}\text { Towards expressive ontology-based approaches to manufacturing } \\
\text { knowledge representation and sharing }\end{array}$ \\
\hline $\begin{array}{l}\text { Colombo; Dell'Era and } \\
\text { Frattini }\end{array}$ & 2015 & $\begin{array}{l}\text { Exploring the contribution of innovation intermediaries to the new } \\
\text { product development (NPD) process: a typology and an empirical } \\
\text { study }\end{array}$ \\
\hline Danilovic and Browning & 2007 & $\begin{array}{l}\text { Managing complex product development projects with design structure } \\
\text { matrices and domain mapping matrices }\end{array}$ \\
\hline Danilovic and Sandkull & 2005 & $\begin{array}{l}\text { The use of dependence structure matrix and domain mapping matrix in } \\
\text { managing uncertainty in multiple project situations }\end{array}$ \\
\hline Demoly et al. & 2013 & $\begin{array}{l}\text { Product relationships management enabler for concurrent engineering and } \\
\text { product lifecycle management }\end{array}$ \\
\hline Demoly et al. & 2010 & $\begin{array}{l}\text { Multiple viewpoint modelling framework enabling integrated product- } \\
\text { process design }\end{array}$ \\
\hline Driessen and Hillebrand & 2013 & $\begin{array}{l}\text { Integrating Multiple Stakeholder Issues in New Product Development: An } \\
\text { Exploration }\end{array}$ \\
\hline Elgh and Sunnersjo & 2007 & An Ontology Approach to Collaborative Engineering For Producibility \\
\hline Fan et al. & 2008 & $\begin{array}{l}\text { Development of a distributed collaborative design framework within peer- } \\
\text { to-peer environment }\end{array}$ \\
\hline Froehle and Roth & 2007 & A resource-process framework of new service development \\
\hline Govindaluri and Cho & 2007 & $\begin{array}{l}\text { Robust design modelling with correlated quality characteristics using a } \\
\text { multi-criteria decision framework }\end{array}$ \\
\hline Gunendran and Young & 2006 & $\begin{array}{l}\text { An information and knowledge framework for multi-perspective design } \\
\text { and manufacture }\end{array}$ \\
\hline He; Hou and Song & 2015 & $\begin{array}{l}\text { Integrating engineering design and analysis using a parameter constraint } \\
\text { graph approach }\end{array}$ \\
\hline
\end{tabular}




\begin{tabular}{|c|c|c|}
\hline Inoue et al. & 2012 & Decision-making support for sustainable product creation \\
\hline Imran and Young & 2016 & $\begin{array}{l}\text { Reference ontologies for interoperability across multiple assembly } \\
\text { systems }\end{array}$ \\
\hline Lagrosen & 2005 & $\begin{array}{l}\text { Customer involvement in new product development; A relationship } \\
\text { marketing perspective }\end{array}$ \\
\hline Lee and Kim & 2007 & $\begin{array}{l}\text { A distributed product development architecture for engineering } \\
\text { collaborations across ubiquitous virtual enterprises }\end{array}$ \\
\hline Lennartson et al. & 2007 & $\begin{array}{l}\text { Sequence Planning for Integrated Product, Process and Automation } \\
\text { Design }\end{array}$ \\
\hline Liao et al. & 2015 & $\begin{array}{l}\text { Semantic annotation for knowledge explicitation in a product lifecycle } \\
\text { management context: a survey }\end{array}$ \\
\hline Lin et al. & 2012 & $\begin{array}{l}\text { A systematic approach for deducing multi-dimensional modelling features } \\
\text { design rules based on user-oriented experiments }\end{array}$ \\
\hline Luh; Chu and Pan & 2010 & $\begin{array}{l}\text { Data management of green product development with generic } \\
\text { modularized product architecture }\end{array}$ \\
\hline Nelson & 2011 & Tackling multiple domains \\
\hline Ouertani and Gzara & 2008 & $\begin{array}{l}\text { Tracking product specification dependencies in collaborative design for } \\
\text { conflict management }\end{array}$ \\
\hline Pasqual and Weck & 2012 & $\begin{array}{l}\text { Multilayer network model for analysis and management of change } \\
\text { propagation }\end{array}$ \\
\hline $\begin{array}{l}\text { Rasoulifar; Eckert and } \\
\text { Prudhomme }\end{array}$ & 2014 & $\begin{array}{l}\text { Supporting communication between product designers and engineering } \\
\text { designers in the design process of branded products: a comparison of } \\
\text { three approaches }\end{array}$ \\
\hline Riou and Mascle & 2009 & Assisting designer using feature modelling for lifecycle \\
\hline Seki and Nishimura & 2011 & $\begin{array}{l}\text { A module-based thermal design approach for distributed product } \\
\text { development }\end{array}$ \\
\hline $\begin{array}{l}\text { Sommer; Dukovska- } \\
\text { Popovska and Steger-Jensen }\end{array}$ & 2013 & $\begin{array}{l}\text { Barriers towards integrated product development }- \text { Challenges from a } \\
\text { holistic project management perspective }\end{array}$ \\
\hline $\begin{array}{ll}\text { Subramani } & \text { and } \\
\text { Gurumoorthy } & \end{array}$ & 2005 & Maintaining associativity between form feature models \\
\hline Tseng; Kao and Huang & 2008 & $\begin{array}{l}\text { A model for evaluating a design change and the distributed manufacturing } \\
\text { operations in a collaborative manufacturing environment }\end{array}$ \\
\hline Usman et al. & 2013 & Towards a formal manufacturing reference ontology \\
\hline Vosinakis et al. & 2008 & $\begin{array}{l}\text { Virtual environments for collaborative design: requirements and } \\
\text { guidelines from a social action perspective }\end{array}$ \\
\hline Zhou; Lin and Liu & 2008 & $\begin{array}{l}\text { Customer-driven product configuration optimization for assemble-to- } \\
\text { order manufacturing enterprises }\end{array}$ \\
\hline
\end{tabular}

\subsection{Step 1b: Scientific papers related to PDP and Product Requirements (Constraints)}

As performed in the step 1a, this step identified the scientific papers related to PDP and

Product Requirements (constraints). It was used the inclusion criteria, as presented in table 1 and the following keywords represented PDP - Integrated Product Development, Product Development Process, Product Design, Manufacturing Design, Design for Manufacturing and Assembly; and representing Product Requirements (constraints) Requirements and Specification. The period is the same of the later step - 10 years (2005-2015). This search found 2,830 articles as illustrate in table 5. 
Table 4. Results obtained regarding PDP and Product Requirements according to the selected keywords.

\begin{tabular}{llll}
\hline Keywords & & & $\begin{array}{l}\text { Results from the } \\
\text { databases }\end{array}$ \\
\hline "Product Development Process" & AND & "Requirements" & 1,515 \\
"Integrated Product Development" & AND & "Requirements" & 293 \\
"Product Design & AND & "Requirements" & 797 \\
"Manufacturing Design" & AND & "Requirements" & 27 \\
"Design for Manufacturing and Assembly" & AND & "Requirements" & 2 \\
"Product Development Process" & AND & "Specification" & 21 \\
"Integrated Product Development" & AND & "Specification" & 1 \\
"Product Design & AND & "Specification" & 168 \\
"Manufacturing Design" & AND & "Specification" & 6 \\
"Design for Manufacturing and Assembly" & AND & "Specification" & 0 \\
\hline Total of found researches & & & $\mathbf{2 , 8 3 0}$ \\
\hline
\end{tabular}

Applying the exclusion criteria, proposed in table 1, 29 articles respected the criteria from the 2,830 articles. The main exclusion criterion was also the domainspecific papers because many articles had a divergent research question focus such as medicine, dentistry, marketing, etc. Thus, each article abstract was analysed and only the articles with the focus on the aim and question of this research were selected. Table 6 presents the research step results that is organised according to the authors, year and research title.

Table 5. Results of the Systematic literature Review on PDP and Product Requirements organised by authors.

\begin{tabular}{lll}
\hline Authors & Year & Title \\
\hline Baïna et al. & 2009 & $\begin{array}{c}\text { New paradigms for a product oriented modelling: Case study for } \\
\text { traceability } \\
\text { framework to integrate design knowledge reuse and requirements } \\
\text { management in engineering design } \text { et al. }\end{array}$ \\
$\begin{array}{l}\text { Belkadi } \text { et al. } \\
\text { meta-modelling framework for knowledge consistency in collaborative } \\
\text { design }\end{array}$ \\
$\begin{array}{l}\text { Bereketli and Genevois } \\
\begin{array}{l}\text { Chang; Sahin and Terpenny } \\
\text { Chen }\end{array}\end{array} 2012$ & $\begin{array}{c}\text { An integrated QFDE approach for identifying improvement strategies in } \\
\text { sustainable product development }\end{array}$ \\
Chen & 2010 & $\begin{array}{c}\text { An ontology-based support for product conceptual design } \\
\text { design and process development }\end{array}$ \\
Darlington and Culley & 2006 & $\begin{array}{c}\text { Classification of product requirements based on product environment } \\
\text { Investigating ontology development for engineering design support }\end{array}$ \\
\hline
\end{tabular}




\begin{tabular}{|c|c|c|}
\hline Huang and Liang & 2006 & $\begin{array}{l}\text { Explication and sharing of design knowledge through a novel product } \\
\text { design approach }\end{array}$ \\
\hline Juan; Ou-Yang and Lin & 2009 & $\begin{array}{l}\text { A process-oriented multi-agent system development approach to support } \\
\text { the cooperation-activities of concurrent new product development }\end{array}$ \\
\hline $\begin{array}{l}\text { Käkölä; Koivulahti-ojala } \\
\text { and Liimatainen }\end{array}$ & 2011 & $\begin{array}{l}\text { An information systems design product theory for the class of integrated } \\
\text { requirements and release management systems }\end{array}$ \\
\hline Kim et al. & 2012 & $\begin{array}{l}\text { Product life cycle information and process analysis methodology: } \\
\text { Integrated information and process analysis for product life cycle } \\
\text { management }\end{array}$ \\
\hline Kim; Manley and Yang & 2006 & $\begin{array}{l}\text { Ontology-based assembly design and information sharing for } \\
\text { collaborative product development }\end{array}$ \\
\hline Krishnapillai and Zeid & 2006 & Mapping Product Design Specification for Mass Customization \\
\hline Lee and Lin & 2011 & An integrated fuzzy QFD framework for new product development \\
\hline Lehto et al. & 2011 & Benefits of DFX in requirements engineering (Design for X) \\
\hline Lin; Chen and Chen & 2009 & $\begin{array}{l}\text { An integrated component design approach to the development of a design } \\
\text { information system for customer-oriented product design }\end{array}$ \\
\hline McFarlane and Cuthbert & 2012 & Modelling information requirements in complex engineering services \\
\hline Ouertani & 2009 & Engineering change impact on product development processes \\
\hline Ouertani et al. & 2011 & $\begin{array}{l}\text { Traceability and management of dispersed product knowledge during } \\
\text { design and manufacturing }\end{array}$ \\
\hline $\begin{array}{l}\text { Parameshwaran; Baskar and } \\
\text { Karthik }\end{array}$ & 2015 & $\begin{array}{l}\text { An integrated framework for mechatronics based product development in } \\
\text { a fuzzy environment }\end{array}$ \\
\hline $\begin{array}{l}\text { Pernstål; Magazinius and } \\
\text { Gorschek }\end{array}$ & 2012 & $\begin{array}{l}\text { A study investigating challenges in the interface between product } \\
\text { development and manufacturing in the development of software- } \\
\text { intensive automotive systems }\end{array}$ \\
\hline Wang; Chan and Li & 2015 & $\begin{array}{l}\text { A case study of an integrated fuzzy methodology for green product } \\
\text { development }\end{array}$ \\
\hline Wu et al. & 2013 & $\begin{array}{l}\text { A distributed collaborative product design environment based on semantic } \\
\text { norm model and role-based access control }\end{array}$ \\
\hline Xu et al. & 2007 & A decision support system for product design in concurrent engineering \\
\hline $\mathrm{Xu}$ et al. & 2011 & $\begin{array}{l}\text { Developing a knowledge-based system for complex geometrical product } \\
\text { specification (GPS) data manipulation }\end{array}$ \\
\hline Yin, Qin and Holland & 2011 & $\begin{array}{l}\text { Development of a design performance measurement matrix for improving } \\
\text { collaborative design during a design process }\end{array}$ \\
\hline Zeng et al. & 2011 & $\begin{array}{l}\text { Product collaborative design method based on a sharing information } \\
\text { model }\end{array}$ \\
\hline Zha and Sriram & 2006 & $\begin{array}{l}\text { Platform-based product design and development: A knowledge-intensive } \\
\text { support approach }\end{array}$ \\
\hline
\end{tabular}

\subsection{Step 2: Analysis and classification of the papers related to Multiple Domains and Product Requirements to support PDP}

As discussed in section 2, there are relevant issues related to Multiple Domain, PDP and Product Requirements and their simultaneous relationship to support the information interoperability across different phases of PD. In a preliminary research, articles that were simultaneously concerning to these three issues were not directly found. Thus, authors proposed a classification for the articles selected in Steps 1a and $1 \mathrm{~b}$ in order to investigate their correlations, solutions, and limitations regarding 
simultaneously the issues: (i) Multiple Domains; (ii) PDP; and (iii) Product Requirements.

The subject analysis of the selected articles in the steps $1 \mathrm{a}$ and $1 \mathrm{~b}$ were performed aiming the investigation of the correlations, solutions, and limitations concerning the three perspectives of PDP, Multiple Domains and Product Requirements (constraints) working simultaneously as presented in Section 2. The criteria for the categorization were defined as (i) Cross-Domains (D); (ii) Cross-Product Development Phases (PD); and (iii) Cross-Product Requirements (Constraints) (R). The criteria definition were crossing the literature information with the research's aims and issues and identifying the most relevant parameters for the articles categorization. The crossdomain (D) was divided into three subclasses:

- (D1) Particular cases - Papers/articles concerning the product information and/or requirements exchange limited to two specific domains;

- (D2) Ability to be general - Papers/articles concerning the product information and/or requirements exchange among different domains and that can be adapted to other domains;

- (D3) General approach - Papers/articles concerning the product information exchange and/or requirements among different domains whose approaches do not need any adaptation.

The cross-Product Development phases (PD) was split into two subclasses:

- (PD1) Considering PDP - For papers/articles that concern the product information and/or requirements exchange among one or more phases of the product development process; 
- (PD2) Not considering PDP - For papers/articles that do not concern the product information and/or requirements exchange among one or more phases of the product development process.

And finally, the cross-requirements was divided into three subclasses:

- (R1) Requirements Traceability - Papers/articles regarding the product information and/or constraints traceability in one or more phases of product development process;

- (R2) Requirements Interoperability - Papers/articles regarding the exchange of product information and/or constraints between one or more phase of product development process and different domains;

- (R3) Requirements Inconsistency Analysis - Papers/articles regarding the product information and/or constraints exchange between one or more phase of product development process and different domains. This sub-issue considers the impacts analysis caused by any product information and/or constraints changes during the product development process.

Based on these 8 criteria, the articles selected in Step 1a and Step 1b were classified as illustrated in table 7.

Table 6 . Related works classification according to the 8 criteria.

\begin{tabular}{l|l|l|l|l|l|l|l|l|}
\hline \multirow{2}{*}{ Authors and Publication Year } & \multicolumn{2}{|l|}{$\begin{array}{l}\text { Multiple } \\
\text { issue }\end{array}$} & Domains & \multicolumn{2}{|c|}{ PDP issue } & \multicolumn{2}{|c|}{ Requirements issue } \\
\hline & (D1) & (D2) & (D3) & (PD1) & (PD2) & (R1) & (R2) & (R3) \\
\hline Augustine et al. (2012) & & & & & & & & \\
Baïna; Panetto and Morel (2009) & & & & & & & \\
Bartolomei et al. (2012) & & & & & & & & \\
Baxter et al. (2008) & & & & & & & \\
Belkadi et al. (2012) \\
$\begin{array}{l}\text { Bereketli and Genevois (2013) } \\
\text { Brusoni and Prencipe (2006) } \\
\text { Canciglieri Jr. and Young (2010) } \\
\text { Chang; Sahin and Terpenny (2008) } \\
\text { Chen (2010) }\end{array}$
\end{tabular}


Chen (2006)

Chen; Wang and Huang (2014)

Christiansen et al. (2010)

Chungoora; Canciglieri Jr. and Young (2010)

Colombo; Dell'Era and Frattini (2015)

Danilovic and Browning (2007)

Danilovic and Sandkull (2005)

Darlington and Culley (2008)

Demoly et al. (2010)

Demoly et al. (2013)

Driessen and Hillebrand (2013)

Elgh and Sunnersjo (2007)

Fan et al. (2008)

Froehle and Roth (2007)

Govindaluri and Cho (2007)

Gunendran and Young (2006)

He; Hou and Song (2015)

Huang and Liang (2006)

Inoue et al. (2012)

Imran and Young (2016)

Juan; Ou-Yang and Lin (2009)

Käkölä; Koivulahti-ojala and Liimatainen (2011)

Kim et al. (2012)

Kim; Manley and Yang (2006)

Krishnapillai and Zeid (2006)

Lagrosen (2005)

Lee and Lin (2011)

Lee and Kim (2007)

Lehto et al. (2011)

Lennartson et al. (2010)

Liao et al. (2015)

Lin et al. (2012)

Lin; Chen and Chen (2009)

Luh; Chu and Pan (2010)

McFarlane and Cuthbert (2012)

Nelson (2011)

Ouertani and Gzara (2008)

Ouertani (2009)

Ouertani et al. (2011)

Pasqual and Weck (2012)

Parameshwaran; Baskar and Karthik (2015)

Pernstål; Magazinius and Gorschek (2012)

Rasoulifar; Eckert and Prudhomme (2014)

Riou and Mascle (2009)

Seki and Nishimura (2011)

Sommer; Dukovska-Popovska and StegerJensen (2013)

Subramani and Gurumoorthy (2005)

Tseng; Kao and Huang (2008)

Usman et al. (2013)

Vosinakis et al. (2008)

Wang; Chan and Li (2015)

Wu et al. (2013)

$\mathrm{Xu}$ et al. (2007)

Zhou; Lin and Liu (2008)

Yin; Qin and Holland (2011)

$\mathrm{Xu}$ et al. (2011) 
The classification of the 68 papers resulted in:

\section{Multiple Domains Issue}

- $86,8 \%$ of articles/papers meet the criterion D1;

- $26,5 \%$ of articles/papers meet the criterion D2;

- $4,4 \%$ of articles/papers meet the criterion D3.

\section{Product Development Process Issue}

- $55,9 \%$ of articles/papers concern the criterion PD1;

- $44,1 \%$ of articles/papers concern the criterion PD1.

\section{Requirements Issue}

- $32,3 \%$ of articles/papers meet the criterion R1;

- $\quad 39,7 \%$ of articles/papers meet the criterion R2;

- $5,9 \%$ of articles/papers concern the criterion R3.

Based on these data, it was observed that there are some poorly explored matters in the multiple domains issue, item (D2) and (D3) and in the requirements issue item (R3). In the multiple domain issue, it was verified that the approaches proposed by the literature solved specific information exchange between domains, but when these approaches are extended to multiples domains (more than three) there are restriction and limitations. This issue makes evident the problem with the semantic gap in multiples domains as well as the risk of mistakes and misinterpretation. In the requirement issue, it was noticed that there are researchers addressing the requirement traceability and interoperability. Nevertheless, these researchers did not consider the impact of frequents 
requirements improvements and variations during the PDP, which caused problems of information consistency.

\subsection{Step 3 - Identification and analysis of all the references cited in the relevant papers.}

This step focused on the milestone references identification based on all references cited in all articles found in the survey of this research. This step is important to understand the main references that are working with semantic interoperability applied to PD. Thus, to individually find the authors most frequently referenced, at first, it was selected the fittest articles to the aim of this research, called criterion (C1). Secondly, all article references were analysed and classified to identify the references frequency.

Criterion (C1) was defined as "scientific articles classified in D2 and/or D3 of multiple domains plus (+) scientific articles classified in PD1 plus (+) scientific articles classified in R1 and/or R2 and/or R3. Criterion (C1) represents the scientific papers approaches that concern (i) Multiple Domains; (ii) PDP; and (iii-a) Requirements (constraints) traceability, (iii-b) ability of information exchange and (iii-c) impact analysis. As the results of this process, the works of Danilovic and Sandull (2005), Subramani and Gurumoorthy (2005), Brusoni and Prencipe (2006), Kim; Manley and Yang (2006), Danilovic and Browning (2007), Baxter et al. (2008), Chang; Sahin and Terpenny (2008), Canciglieri and Young (2010), Chen (2010), Demoly et al. (2010), Ouertani et al. (2011), Belkadi et al. (2012), Wu et al. (2013) and Liao et al. (2015) met C1. Based on the selected articles, all references were analysed and the frequency was identified and is shown in Table 8. In this table, "row" refers to the authors" production related to the different works and "column" refers to the scientific papers selected.

Table 7. Reference frequency distribution by 14 articles selected. 


\begin{tabular}{|c|c|c|c|c|c|c|c|c|c|c|c|c|c|c|c|c|}
\hline & 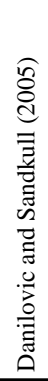 & 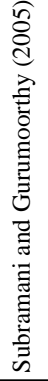 & 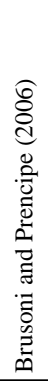 & 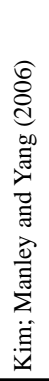 & 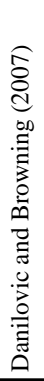 & 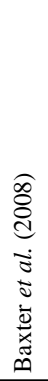 & 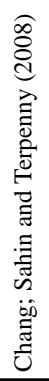 & 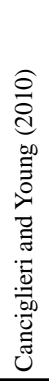 & 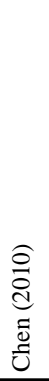 & 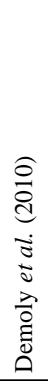 & 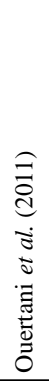 & 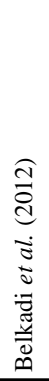 & 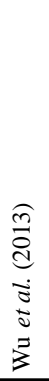 & 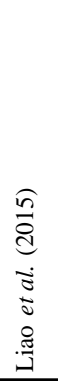 & 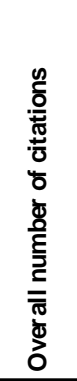 & 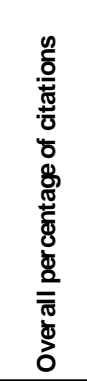 \\
\hline Eppinger S.D. & 7 & & & & 5 & & & & & & & & & & 12 & $0,9 \%$ \\
\hline Danilovic M. & 5 & & & & 6 & & & & & & & & & & 11 & $0,8 \%$ \\
\hline Young R.I.M. & & & & & & 2 & & 5 & & & 1 & 1 & & 1 & 10 & $0,8 \%$ \\
\hline Panetto H. & & & & & & & & & & & & 3 & & 5 & 8 & $0,6 \%$ \\
\hline Bronsvoort W.F. & & 5 & & 1 & & & & & & 1 & & & & & 7 & $0,5 \%$ \\
\hline Browning T.R. & 4 & & & & 3 & & & & & & & & & & 7 & $0,5 \%$ \\
\hline Canciglieri $\mathrm{O}$. & & & & & & & & 5 & & & & & & 1 & 6 & $0,5 \%$ \\
\hline Sriram R.D. & & & & & & 1 & & & & 2 & 2 & 1 & & & 6 & $0,5 \%$ \\
\hline Steward D. & 3 & & & & 2 & & & & & & & & & & 5 & $0,4 \%$ \\
\hline Carley K.M. & & & & & 5 & & & & & & & & & & 5 & $0,4 \%$ \\
\hline Mizoguchi R. & & & & 5 & & & & & & & & & & & 5 & $0,4 \%$ \\
\hline Whitney D.E. & 2 & & & 2 & & & & & & 1 & & & & & 5 & $0,4 \%$ \\
\hline $\begin{array}{l}\text { Authors with } 4 \text { citations } \\
\text { (14 authors) }\end{array}$ & 7 & 7 & & 2 & 4 & 9 & & 2 & 3 & 2 & 3 & 1 & 8 & 8 & 56 & $4,2 \%$ \\
\hline $\begin{array}{c}\text { Authors with } 3 \text { citations } \\
\text { ( } 29 \text { authors) }\end{array}$ & 2 & 3 & 2 & 6 & 5 & 4 & 1 & 3 & 2 & 8 & 5 & 8 & 8 & 30 & 87 & $6,5 \%$ \\
\hline $\begin{array}{c}\text { Authors with } 2 \text { citations } \\
\text { (118 authors) }\end{array}$ & 12 & 19 & 26 & 9 & 14 & 27 & 7 & 2 & 4 & 19 & 18 & 27 & 5 & 46 & 235 & $17,7 \%$ \\
\hline $\begin{array}{c}\text { Authors with } 1 \text { citations } \\
\text { (865 authors) }\end{array}$ & 21 & 31 & 32 & 53 & 28 & 59 & 25 & 68 & 51 & 61 & 76 & 77 & 32 & 250 & 864 & $65,0 \%$ \\
\hline Total & & & & & & & & & & & & & & & 1,329 & $100,0 \%$ \\
\hline
\end{tabular}

As a result of this process, Eppinger, Danilovic, Young, Panetto, Bronsvoort, Browning, Canciglieri Jr. and Sriram were found to be the most referenced authors (frequency of over 5 citations). Therefore, it is possible to conclude that these names have an important representation in this field as well as their approaches impact directly in semantic interoperability solutions. 


\subsection{Step 4 - Main researches critical analysis and guidelines to semantic interoperability for an integrated product development process}

The systematic literature review resulted in 14 articles that are the references for this research. Thus, this section explores the approaches proposed in each work and their contributions and limitations, as follows:

1) Danilovic and Sandkull, (2005) - The authors proposed an approach to introduce dependency structure matrix and domain mapping matrix that enables the systematic identification of interdependencies and relations in a Multi-project environment. The approaches enable clarifications of assumptions, the tractability of dependencies, explores the information needed within and between different departments, projects, and people. This creates a transparency and enables the synchronisation of actions through the transformation of information and exploration of assumptions within and between domains. This approach only systematises the information relationships across PDP, but it does not consider the meaning associated to the information captured and their impact in other domains;

2) Subramani and Gurumoorthy, (2005) - The researchers presented an algorithm that takes multiple feature models of a part as input and modifies other feature models to reflect the changes made to a feature in a feature model. The proposed algorithm updates feature volumes in other feature models and then classifies the updated volumes to obtain the updated feature model. The algorithm has a tendency to a general approach, but it is limited to the interaction between specific domains; 
3) Brusoni and Prencipe, (2005) - The researchers investigated the organisation's process to propose a new structure to the product development with radical innovations. This research was limited to the process systematisation with multiple domains and thus, it does not address the information exchange across these heterogeneous domains;

4) Kim, Manley and Yang, (2006) - The authors developed a new paradigm of ontology-based assembly design. The authors proposed an assembly design (AsD) ontology that serves as a formal, explicit specification of assembly design, so that, it makes assembly knowledge both machine-interpretable and to be shared. An Assembly Relation Model (ARM) is enhanced, using ontologies that represent engineering, spatial, assembly and joining relations of assembly in a way that promotes collaborative assembly information-sharing environments. In the developed AsD ontology, implicit AsD constraints are explicitly represented using OWL (Web Ontology Language) and SWRL (Semantic Web Rule Language). Although this research was limited to the assembly domain, the integration of OWL plus (+) SWRL is hypothetically interesting to overcome the semantic interoperability issues in Product Design and Manufacturing. This research presents potential applicability in the use of ontology to formalise heterogeneous information and relationships;

5) Danillovic and Browning, (2007) - The researchers proposed an approach to handling the complexity in the product development process and multiple domains through the Design Structure Matrix (DSM) and Domain Mapping Matrix (DMM). DSM was used to handle dependencies and relations between 
items of product development, but DSM allows modelling the dependencies of one type of single information with other. DMM allows relating two or more DSM. This approach does not enable the interoperability between information as well as the analysis the impact when information changes;

6) Baxter et al., (2008) - The authors developed a framework to add requirements management capability to a knowledge reuse design method. The mapping of the various product domains links the product structure to the requirement source. The database structure provided by the knowledge reuse design system supports a dynamic management of the emergent requirements and developing design data. Although this framework presents a solution to establish links between requirements or constraints and product development in order to ensure the correct design, the approach does not address the information formalisation and their relationships across other phases of the PDP;

7) Chang, Sahin and Terpenny (2008) - The researchers proposed an approach to support designers in the conceptual design stage. An ontology-based approach for knowledge management, which works along with the graphical modelling tool, to support designers in generating flexible, fast, and easy design concepts was discussed and developed. In addition, different methods are proposed to offer support to the users, such as the relationship between the ontology and databases, the data analysis process, ontology enrichment, and the ontology-based query engine. This research has an interesting approach (ontology plus (+) query engine) to support the semantic interoperability in the product design and manufacturing, even though it was limited in a specific phase of PDP; 
8) Canciglieri Junior and Young (2010) - The researchers proposed a conceptual multiple view approach model using object-oriented model and UML to map information relationships between designs and manufacturing domains based on translation mechanisms. Each mechanism had a specific knowledge, which was responsible for translating the information from one view to another. Despite this solution, this research presented limited mechanisms to specific domains, but the information structure and the translation mechanisms are theoretically applicable to interoperability in product design and manufacturing;

9) Chen (2010) - The author presented a systematic approach for developing knowledge integration and sharing mechanism for collaborative moulding product design and process development. The proposed approach includes the steps of (i) collaborative moulding product design and process development process modelling, (ii) an ontology-based knowledge model establishment, and (iii) knowledge integration and sharing system framework design, development and implementation. The relationships and changing analysis are not addressed, even though this research structures the information. However, the result of this approach significantly contributes to the semantic interoperability in product design and manufacturing framework based on ontological approach;

10) Ouertani et al., (2011) - The researchers proposed a standardised approach for tracing and sharing product knowledge. Furthermore, key constructions to support traceability during the product development process are identified and formalised. The proposed approach was implemented using the MEGA Suite tool. This 
research does not address the information interoperability across multiple domains as well as the information changing across PDP;

11) Belkadi et al., (2012) - The authors investigated a new meta-model in a ModelDriven Engineering (MDE) approach to managing the integration of heterogeneous experts' knowledge models in a collaborative process. This metamodel is split in a meta-model of data and collaboration meta-model to represent the distinction between the core concepts of knowledge and additional elements. It serves to represent the relation between these concepts and between concepts of heterogeneous experts' models. The research allows the communication between different tools (CAD, CAS, PDM), but the information interoperability across PDP is not considered. However, the approach works with core concepts and semantic mapping that are used to support the heterogeneity of information between models, which currently occurs during a collaborative project;

12) Demoly et al., (2013) - A product relationship management approach called PROMA is proposed and implemented in a new application called PEGASUS in connection with PDM, MPM and CAD systems. The proposed approach enables the control of internal regulation procedures between product design and assembly sequence planning phases, so as to provide a proactive and interactive support for lifecycle oriented product development. Semantic interoperability and their relationships are not completely achieved, even though the approach proposed by the researchers enriches the information based on the connection with different platforms; 
13) Wu et al., (2013) - The authors proposed a Semantic Norm Model (SNM) for product design. A high-level semantic constraint system is presented in the conceptual design to link the gaps between product conceptual and detailed design and a Role-Based Access Control (RBAC) system is constructed to support distributed collaborative product design. Thus, based on the SNM and RBAC system, a distributed collaborative product design environment is established, allowing distributed designers to work collaboratively and concurrently. This research does not address the information interoperability across multiple domains and information changing across PDP;

14) Liao et al., (2015) - A formalisation of semantic annotation for system interoperability from the view of different domains in a Product Life Cycle Management environment is proposed. The formalisation made explicit the tacit knowledge in application models and provided support for all activities during the product life cycle. Semantic links are established with different domains and potentially contributes to semantic interoperability across PDP, even though this approach did not depict the information interoperability across PDP.

The analysis of the 14 articles has shown that the researches of Canciglieri Junior and Young (2010); Kim, Manley and Yang, (2006); Belkadi et al. (2012); and Liao et al., (2015) were the major references for this research scope. The approaches proposed by these researchers have demonstrated potential to solve the problems of semantic interoperability in product design and manufacturing, although without a holistic perception. Cancigleiri Junior and Young (2010), proposed an information data structure and relationships mechanisms rigorously defined for product design and 
manufacturing, based on feature technology that was applied to plastic injection moulded product. Kim, Manley and Yang, (2006) used ontology in OWL and modelled semantic rules in SWRL, to formalise information in assembly design and depicted the applicability of ontology to solve semantic interoperability issues. Belkadi et al. (2012) used the "core concepts" to formalise foundations knowledge and established a semantic mapping to relate different core concepts. Liao et al., (2015) proposed semantic annotations to enrich the information relationships across PLM that can be extended to the PDP

The content analysis showed that there is no general and integrated semantic interoperability approach that solves the relation between Domain, PDP, and Product Constraints. The contributions revealed that several proposed solutions are applicable and can be improved to meet the field needs. The limitations helped the issues identification serving as a guide for new studies. In this context, it can be said that the content analysis offered the knowledge board as well as the potential to extend it through new researches opportunities on semantic interoperability applied into Product Design and Manufacturing process.

\section{Conclusions}

This paper presented a systematic literature review concerning the semantic interoperability for an integrated product development process. It is evident that in the product development scenario, thousands of information must be effectively shared across different phases of product development process without any loss of information and knowledge meaning and intent. In addition, misinterpretation and mistakes such as tons of colour, geometric shapes, surface roughness and so on have been identified in product requirements across the PDP due to the heterogeneity of information. So that, this research has identified the main recent researches and the milestones references in 
the literature in order to support the semantic interoperability across product development process.

The research outcomes were 3,607 scientific articles with high impact factor, based on inclusion criteria such as keywords, abstract, published period and primary studies. However, it was necessary to apply the exclusion criteria such as subject analysis, secondary studies, and non-English written papers in order to identify the most adherent articles to the research subject, which resulted in 68 articles. These articles were analysed and categorised according to 8 criteria that were defined for identifying the most relevant parameters for the research aim. This analysis and categorization pointed out 14 articles and 8 authors that were the most relevant researches and the milestones references in the studied area, presenting the knowledge boundaries of this field and offering opportunities to extend it.

The research overview has shown that less than $30 \%$ of the works found in the literature concerned the information sharing between more than two heterogeneous domains (criteria D2 and D3); less than 40\% concerned the information traceability and/or information interoperability and/or inconsistencies analysis. These results demonstrate that the semantic interoperability lacks across PDP need to be effectively addressed by the scientific academy to ensure the correct information and knowledge interoperability and to reduce the misinterpretation and mistakes during the PDP phases.

Finally, the research focus was the scientific subject addressed on each studied paper to identify the potential contributions and limitations to support the semantic interoperability. It is evident that this research field has interesting opportunities for the exploration of semantic interoperability to support the product development process in order to reduce the development time and costs as well as to improve the product quality. As future work, the authors are proposing the development of a conceptual 
framework to support the semantic interoperability in the product design and manufacturing. The idea of the conceptual framework should provide a contribution in the area of decision-making support system based on the use of product and manufacturing model to provide seamless information interoperability for design and manufacturing activities.

\section{Acknowledgements}

The authors would like to thank the Coordination of Improvement of Higher Education Personnel - CAPES, under the Science without Borders Program (Special Visiting Researcher) - Project 178/2012 and Pontifical Catholic University of Parana (PUCPR) for the financial support.

\section{References}

Augustine M., O. Yadav, R. Jain, and A. Rathore. 2012. "Cognitive map-based system modeling for identifying interaction failure modes." Research in Engineering Design 23 (2): 105-124.

Baïna, S., H. Panetto, and G. Morel. 2009. "New paradigms for a product oriented modelling: Case study for traceability." Computers in Industry 60 (3): 172-183.

Bartolomei, J., D. Hastings, R. de Neufville, and D. Rhodes. 2012. "Engineering Systems Multiple-Domain Matrix: An organising framework for modelling large-scale complex systems." Systems Engineering 15(1): 41-61.

Baxter, D., J. Gao, K. Case, J. Harding, B. Young, S. Cochrane, and S. Dani. 2008. “A framework to integrate design knowledge reuse and requirements management in engineering design." Robotics and Computer-Integrated Manufacturing 24 (4): 585-593.

Belkadi, F., N. Dremont, A. Notin, N. Troussier, and M. Messadia. 2012. "A metamodelling framework for knowledge consistency in collaborative design." Annual Reviews in Control 36 (2): 346-358. 
Bereketli I., and M. E. Genevois. 2013. “An integrated QFDE approach for identifying improvement strategies in sustainable product development." Journal of Cleaner Production 54: 188-198.

BKCASE, Editorial Board. 2016. "The Guide to the Systems Engineering Body of Knowledge (SEBoK).” Version 1.6. R.D. Adcock (EIC), Hoboken, The Trustees of the Stevens Institute of Technology. Accessed 28 March 2016. http://www.sebokwiki.org.

Brusoni, S., and A. Prencipe. 2006. "Making Design Rules: A Multi-Domain Perspective." Organization of Science 17 (2): 179-191.

Canciglieri Jr., O., and R. I. M. Young. 2003. "Information sharing in multiviewpoint injection moulding design and manufacturing." International Journal of Production Research 41 (7): 1565-1586.

Canciglieri Jr., O., and R. I. M. Young. 2010. "Information mapping across injection moulding design and manufacture domains." International Journal of Production Research 41 (7): 4437-4462.

CAPES. 2017. Periodicos CAPES - Coordination for the Improvement of Higher Education Personnel. Accessed 08 March 2017. http://www-periodicos-capesgov-br.ez433.periodicos.capes.gov.br/index.php?option=com_pmetabusca\&mn= $70 \&$ smn $=78 \&$ base $=$ find-db-1\&type $=$ b $\&$ Itemid $=121$

Chang, X., A. Sahin, and J. Terpenny. 2008. “An ontology-based support for product conceptual design." Robotics and Computer-Integrated Manufacturing 24 (6): $755-762$.

Chen, L., W. Wang, and B. Huang. 2014. "A negotiation methodology for multidisciplinary collaborative product design." Advanced Engineering Informatics 28 (4): 469-478.

Chen, Y.-J. 2010. "Knowledge integration and sharing for collaborative molding product design and process development." Computers in Industry 61 (7): 659675.

Chen, Z. 2006. "Classification of product requirements based on product environment." Concurrent engineering: research and applications 14 (3): 219-229.

Christiansen, J. K., C. J. Varnes, M. Gasparin, D. Storm-Nielsen, and E. J. Vinther. 2010. "Living Twice: How a Product Goes through Multiple Life Cycles" Journal of Product Innovation Management 27: 797-828. 
Chungoora, N., O. Canciglieri Jr., and R. I. M. Young. 2010. "Towards expressive ontology-based approaches to manufacturing knowledge representation and sharing." International Journal of Computer Integrated Manufacturing, 23 (12): 1059-1070.

Chungoora, N., R. I. M. Young, G. Gunendran, C. Palmer, Z. Usman, N. A. Anjum, A.F. Cutting-Decelle, J. A. Harding, and K. Case. 2013. "A model-driven ontology approach for manufacturing system interoperability and knowledge sharing." Computers in Industry 64 (4): 392-401.

Colombo, G., Dell' Era, C., and Frattini, F. 2015. "Exploring the contribution of innovation intermediaries to the new product development ( NPD ) process: a typology and an empirical study.” R\&D Management 45 (2): 126-146.

Danilovic M., and B. Sandkull. 2005. "The use of dependence structure matrix and domain mapping matrix in managing uncertainty in multiple project situations." International Journal of Project Management 23 (3): 193-203.

Danilovic, M., and T. R. Browning. 2007. "Managing complex product development projects with design structure matrices and domain mapping matrices." International Journal of Project Management 25 (3): 300-314.

Darllington, M. J. and S. J. Culley. 2008. "Investigating ontology development for engineering design support." Advanced Engineering Informatics 22 (1):112-134.

Demoly F., D. Monticolo, B. Eynard, L. Rivest, and S. Gomes. 2010. "Multiple viewpoint modelling framework enabling integrated product-process design." International Journal on Interactive Design and Manufacturing (IJIDeM) 4 (4): 269-280.

Demoly, F., O. Dutartre, X.-T. Yan, B. Eynard, D. Kiritsis, and S. Gomes. 2013. "Product relationships management enabler for concurrent engineering and product lifecycle management." Computers in Industry 64 (7): 833-848.

Driessen, P. H., and B. Hillebrand. 2013. "Integrating Multiple Stakeholder Issues in New Product Development: An Exploration." Journal of Product Innovation Management 30 (2): 364-379.

Elgh, F., and S. Sunnersjo. 2007. “An Ontology Approach to Collaborative Engineering for Producibility." International Journal of e-Collaboration 3 (4): 21-45.

Fan L. Q., A. Senthil Kumar, B. N. Jagdish, and S. H. Bok. 2008. "Development of a distributed collaborative design framework within peer-to-peer environment." Computer-Aided Design 40 (9): 891-904. 
Froehle, C. M., and A. V. Roth. 2007. "A resource-process framework of new service development." Production and Operations Management 16 (2): 169-188.

Govindaluri, S. and B. Cho. 2007. "Robust design modeling with correlated quality characteristics using a multicriteria decision framework." International Journal of Advanced Manufacturing Technology 32 (5): 423-433.

Gunendran, A. G., and R. I. M. Young. 2007. "An information and knowledge framework for multiple-perspective design and manufacture." International Journal of Advanced Manufacturing Technology 32 (5): 423-433.

He, B., S. Hou, and W. Song. 2015. "Integrating engineering design and analysis using a parameter constraint graph approach.” Simulation 91 (7): 625-647.

Huang, C-C., and W. Y. Liang. 2006. "Explication and sharing of design knowledge through a novel product design approach.” IEEE Transactions on Systems, Man, and Cybernetics - Part C 36 (3): 426-438.

Imran, M. and R. I. M. Young. 2016. "Reference ontologies for interoperability across multiple assembly systems." International Journal of Production Research 54 (18): 5381-5403.

Inoue, M, K. Lindow, R. Stark, K. Tanaka, Y-E. Nahm, and H. Ishikawa. 2012. "Decision-making support for sustainable product creation." Advanced Engineering Informatics 26 (4): 782-792.

ISO/IEC 42010. 2007. Systems and Software Engineering -- Recommended Practice for Architectural Description of Software-Intensive Systems. ISO/IEC 42010:2007. Geneva: ISO.

Jesson, J., and D. Lacey. 2006. "How to do (or not to do) a critical review." Pharm Educ 6:139-148.

Juan, Y-C., C. Ou-Yang, and J-S. Lin. 2009. "A process-oriented multi-agent system development approach to support the cooperation-activities of concurrent new product development." Computers \& Industrial Engineering 57 (4): 1363-1376.

Käkölä, T., M. Koivulahtiojala, and J. Liimatainen. 2011. “An information systems design product theory for the class of integrated requirements and release management systems." Journal of Software Maintenance and Evolution: Research and Practice 23 (6) 443-463.

Kim, G.-Y, Lee, J.-Y, Park, Y. H., and Noh, S. D. 2012. "Product life cycle information and process analysis methodology: Integrated information and process analysis for product life cycle management." Concurrent Engineering 20 (4): 257-274. 
Kim, K.-Y., D. G. Manley, and H. Yang. 2006. “Ontology-based assembly design and information sharing for collaborative product development." Computer-Aided Design 38 (12): 1233-1250.

Krishnapillai R., and A. Zeid. 2006. "Mapping Product Design Specification for Mass Customization.” Journal of Intelligent Manufacturing 17 (1): 29-43.

Lagrosen, S. 2005. "Customer involvement in new product development: A relationship marketing perspective." European Journal of Innovation Management 8 (4): 424-436.

Lee J., and K. Kim. 2007. "A distributed product development architecture for engineering collaborations across ubiquitous virtual enterprises." International Journal of Advanced Manufacturing Technology 33 (1): 59-70.

Lee, A., and C-Y. Lin. 2011. “An integrated fuzzy QFD framework for new product development." Flexible Services and Manufacturing Journal 23 (1): 26-47.

Lehto, J., J. Harkonen, H. Haapasalo, P. Belt, M. Mottonen, and P. Kuvaja. 2011. "Benefits of DFX in requirements engineering." Technology and Investment 2 (1): 27-38.

Lennartson, B., K. Bengtsson, K. Chengyin Yuan, M. Andersson, P. Fabian, K. Falkman, and K. Akesson. 2010. "Sequence Planning for Integrated Product, Process and Automation Design." IEEE Transactions on Automation Science and Engineering 7 (4): 791-802.

Liao Y., M. Lezoche, H. Panetto, N. Boudjlida, and E. R. Loures. 2015. "Semantic annotation for knowledge explicitation in a product lifecycle management context: a survey." Computers in Industry 71:24-34.

Lin L., M.-Q. Yang, J. Li, and Y. Wang. 2012. "A systematic approach for deducing multi-dimensional modeling features design rules based on user-oriented experiments.” International Journal of Industrial Ergonomics 42 (4): 347-358.

Lin, M-C., L-A. Chen, and M-S. Chen. 2009. "An integrated component design approach to the development of a design information system for customeroriented product design.” Advanced Engineering Informatics 23 (2) 210-221.

Luh, Y.-P., C.-H. Chu, and C.-C. Pan. 2010. "Data management of green product development with generic modularized product architecture." Computers in Industry 61 (3): 223-234. 
Mattioda, R. A., A. Mazzi, O. Canciglieri Jr., and A. Scipioni. 2015. "Determining the principal references of the social life cycle assessment of products." International Journal of Life Cycle Assessment 20: 1155-1165.

McFarlane, D., and R. Cuthbert. 2012. "Modelling information requirements in complex engineering services." Computers in Industry 63 (4): 349-360.

Moher, D., A. Liberati, J. Tetzlaff, and D. G. Altman. 2009. "Preferred reporting items for systematic review and meta-analyses: the PRISMA statement." Ann Intern Med 151: 264-270.

Nelson, R. 2011. "Tackling multiple domains." Test \& Measurement World 31 (9): 2226.

Negri, E., L. Fumagalli, M. Garetti and L.Tanca. 2016. "Requirements and languages for the semantic representation of manufacturing systems". Computers in Industry 81: 55-66.

Ouertani, M. Z. 2009. "Engineering change impact on product development processes." Systems Research Forum 3 (1): 25-37.

Ouertani, M. Z., S. Baïna, L. Gzara, and G. Morel. 2011. "Traceability and management of dispersed product knowledge during design and manufacturing." ComputerAided Design 43 (5) 546-562.

Ouertani, M.Z., and Gzara, L. 2008. "Tracking product specification dependencies in collaborative design for conflict management." Computer-Aided Design 40 (7): 828-837.

Palmer, C., E. N. Urwin, R. I. M. Young, E, Marilungo. 2017. “A reference ontology approach to support global product-service production.” Inderscience. (in-press)

Panetto, H., M. Dassisti, and A. Tursi. 2012. “ONTO-PDM: Product-driven ONTOlogy for Product Data Management interoperability within manufacturing process environment." Advanced Engineering Informatics 26 (2): 334-348.

Parameshwaran, R., C. Baskar, and T. Karthik. 2015. “An integrated framework for mechatronics based product development in a fuzzy environment." Applied Soft Computing Journal 27: 376-390.

Pasqual, M. and O. Weck. 2012. "Multilayer network model for analysis and management of change propagation.” Research in Engineering Design 23 (4): 305-328. 
Penciuc, D., A. Durupt, F. Belkadi, B. Eynard, and H. Rowson. 2014. "Towards a PLM Interoperability for a Collaborative Design Support System.” Procedia CIRP 25: 369-376.

Pereira J. A. and O. Canciglieri Junior. (2016). "Modelo de Desenvolvimento Integrado de Produto Orientado para Projetos de P\&D do Setor Elétrico Brasileiro.” Novas Edições Acadêmicas/OmniScriptum GmbH \& Co. KG, Saarbrücken, pp. 1-204.

Petti, L., C. M. L. Ugaya, and S. Di Cesare. 2014. "Systematic review of social lifecycle assessment (S-LCA) case studies impact assessment method." In: Macombe, C., and Loeillet D. (eds.) Pre-proceedings of the 4th International Seminar in Social LCA FruiTrop Thema, 34-41.

Quintana-García, C. and C. A. Benavides-Velasco. 2008. "Innovative competence, exploration and exploitation: The influence of technological diversification." Research Policy 37 (3): 492-507.

Rasoulifar, G., C. Eckert, G. Prudhomme. 2014. "Supporting communication between product designers and engineering designers in the design process of branded products: a comparison of three approaches." CoDesign 10 (2): 135-152.

Riou, A. and C. Mascle. 2009. "Assisting designer using feature modeling for lifecycle." Computer-Aided Design 41 (12): 1034-1049.

Rozenfeld, H., F. A. Forcellini, D. C. Amaral, J. C. Toledo, S. L. Silva, D. H.

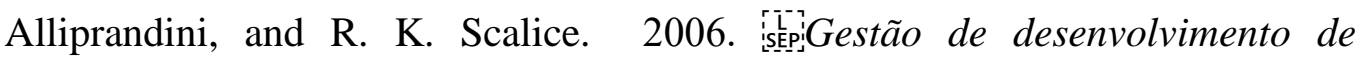
produtos: uma referência para a melhoria do processo [Product Development Management: a reference to improve the process]. São Paulo: Saraiva.

Schlechtendahl, J., M. Keinert, F. Kretschmer, A. Lechler and A. Verl. 2015. "Making existing production systems Industry 4.0-ready: Holistic approach to the integration of existing production systems in Industry 4.0 environments." Production Engineering 9 (1): 143-148.

Seki, K., and H. Nishimura. 2011. "A module-based thermal design approach for distributed product development." Research in Engineering Design 22 (4): 279295.

Sommer, A. F., I. Dukovska-Popovska, and K. Steger-Jensen. 2014. "Barriers towards integrated product development - Challenges from a holistic project management perspective." International Journal of Project Management 32 (6): 970-982. 
Szejka, A. L., A. Aubry, H. Panetto, O. Canciglieri Junior, and E. R. Loures. 2014. "Towards a Conceptual Framework for Requirements Interoperability in Complex Systems Engineering.” Lecture Notes in Computer Science 8842: 229_ 240.

Szejka, A. L., O. Canciglieri Junior, E. R. Loures, H. Panetto, and A. Aubry. 2015. "Requirements Interoperability Method to Support Integrated Product Development." Paper presented at 45th Conference on Computers and Industrial Engineering, Metz, October 28-30.

Szejka, A. L., O. Canciglieri Junior, E. R. Loures, H. Panetto and A. Aubry. 2016. "Proposal of a Model-Driven Ontology for Product Development Process Interoperability and Information Sharing." Springer International Publishing/IFIP International Federation for Information Processing 492 (15): $1-11$.

Tseng, Y-J., Y-W. Kao, F-Y Huang. 2008. "A model for evaluating a design change and the distributed manufacturing operations in a collaborative manufacturing environment." Computers in Industry 59 (8): 798-807.

Usman, Z., R. I. M. Young, N. Chungoora, C. Palmer, K. Case, and J. A. Harding. 2013. "Towards a formal manufacturing reference ontology." International Journal of Production Research 51 (22): 6553-6572.

Vosinakis, S., P. Koutsabasis, M. Stavrakis, N. Viorres, J. Darzentas. 2008. "Virtual environments for collaborative design: requirements and guidelines from a social action perspective." CoDesign 4 (3): 133-150.

Wang, H. W. and H. M., Zhang. 2008. "An integrated and collaborative approach for complex product development in distributed heterogeneous environment." International Journal of Production Research 46 (9): 2345-2361.

Wang, X., H. K. Chan, and D. Li. 2015. "A case study of an integrated fuzzy methodology for green product development.” European Journal of Operational Research, 241 (1): 212-223.

Wu, T., X. Pei, Y. Lu, C. Chen, and L. Gao. 2013. “A distributed collaborative product design environment based on semantic norm model and role-based access control." Journal of Network and Computer Applications 36 (6): 1431-1440.

Xu Y., Z. Xu, X. Jiang, and P. Scott. 2011. "Developing a knowledge-based system for complex geometrical product specification (GPS) data manipulation." Knowledge-Based Systems 24 (1): 10-22. 
Xu, L., Z. Li, S. Li, and F. Tang. 2007. “A decision support system for product design in concurrent engineering." Decision Support Systems 42 (4): 2029-2042.

Yin, Y., S. Qin, and R. Holland. 2011. "Development of a design performance measurement matrix for improving collaborative design during a design process." International Journal of Productivity and Performance Management 60 (2): 152-184.

Zeng, M. L. and L. M. Chan. 2009. "Semantic Interoperability." Encyclopaedia of Library and Information Sciences Taylor \& Francis.

Zeng, P., Y. Hao, W. Shao, and Y. Liu. 2011. "Product collaborative design method based on a sharing information model." Journal of Advanced Manufacturing Systems 10 (1): 191-198.

Zha, X. F. and R. D. Sriram. 2006. "Platform-based product design and development: A knowledge-intensive support approach.” Knowledge-Based Systems 19 (7): 524543.

Zhou, C., Z. Lin and C. Liu. 2008. "Customer-driven product configuration optimization for assemble-to-order manufacturing enterprises." International Journal of Advanced Manufacturing Technology 38 (1): 185-194. 